\title{
PENGELOLAAN PENDATAAN BELANJA KONSUMEN TOKO 212 MART TEGAL
}

\author{
Jatmiko Indriyanto ${ }^{1}$, Adi Candra Kusuma ${ }^{2}$, Prasetya Putra Nugraha ${ }^{3}$ \\ ${ }^{123}$ Politeknik Harapan Bersama \\ ${ }^{123}$ J1.Mataram Pesurungan Lor 521472 Jawa Tengah Indonesia \\ 1jatmikoindri@yahoo.com \\ 2 candraraden45@gmail.com \\ 3 nugrahaputraprasetya@gmail.com
}

\begin{abstract}
Abstrak
Toko 212Mart melakukan transaksi jual beli setiap harinya, yang melakukan transaksi belanja biasanya anggota maupun non anggota. Pendataan transaksi belanja anggota merupakan hal yang penting, karena berkaitan dengan pembagian SHU setiap setahun sekali. Untuk saat ini pendataan masih menggunakan Microsoft excel, sering terjadi kesalahan pendataan, data hilang atau salah pendataan. Maka dibutuhkan aplikasi pendataan anggota belanja agar tidak terjadi kesalahan. Metode penelitian yang digunakan adalah prototype. Dengan adanya aplikasi ini, anggota yang belanja tersebut bisa mengetahui total belanja dan total belanja selama setahun yang bisa dilihat melalui web. Aplikasi yang digunakan untuk mengimplementasikan penelitian ini yaitu aplikasi Netbeans. Metode yang digunakan dalam penelitian kali ini adalah deskriptif. Hasil pengujian menunjukkan bahwa penggunaan aplikasi mengurangi kesalahan pendataan belanja anggota.
\end{abstract}

Kata Kunci: Toko212 mart, belanja anggota.

\section{Pendahuluan}

Pendirian dilakukan pada hari Jum'at 15 Juni 2018 di Jl. Werkudoro Kota Tegal didirikan oleh koperasi Berkah Umat Bersatu yang termasuk dalam Komunitas 212. Ustad Fitrah mengatakan, pendirian bertujuan menumbuhkan potensi ekonomi umat, "Semangatnya, agar umat mandiri secara ekonomi. Setelah Aksi Bela Islam (ABI) 3 atau yang lebih dikenal dengan aksi 212, gara-gara sebuah merk roti, kita baru sadar pentingnya membangun kekuatan ekonomi umat Islam. Semua umat islam mendukung gerakan ini dan dari berbagai kalangan, termasuk kami yang di Tegal", kata Ustad Fitrah. Kepemilikan 212Mart adalah berjamaah, setidaknya ada 150 orang bergabung dalam pendirian 212Mart ini melalui Koperasi Komunitas Muslim kota Tegal. Koperasi ini, bersama umat Muslim kota Tegal lainnya memang tergabung dalam wadah Komunitas Koperasi Syariah 212 Tegal . Komunitas Koperasi Syariah 212 Tegal ini sendiri jumlah anggotanya tak kurang dari 200-an orang ini, terdiri dari 230-an anggota Komunitas Mujahidah Al-Maidah dan sekitar 180 anggota KS 212 di wilayah Kota Tegal yang bergabung ke komunitas ini. Setiap akhir tahun yang diinginkan anggota ialah adanya pembagian SHU (Sisa Hasil Usaha). Sisa hasil usahan didapatkan dari setiap anggota yang belanja di toko212. Untuk saat ini pencatatan belanja anggota masih menggunakan buku tulis, sering misalkan toko lagi ramai, data belanja anggota tidak tercatat atau total belanja salah jumlahnya. Atau anggota yang belanja ditoko, tidak menyebutkan sebagai anggota dan pegawai toko juga tidak menanyakan sehingga tidak tercatat. Beberapa pengurus koperasi sudah rapat dan merumuskan cara paling tepat untuk menyelesaikan masalah ini, salah satu cara adalah dibikinkan kartu anggota, tapi solusi tersebut belum menyelesaikan masalah pendataan belanja anggota, karena setiap belanja anggota menunjukkan kartu, kemudian data belanja dicatat secara manual. Untuk aplikasi yang saat ini tidak bisa menampilkan lporan keuangan seperti rugi laba, sisa stok barang.

\section{Metode Penelitian}

Penelitian ini bertujuan untuk membuat produk berupa aplikasi computer untuk mempermudah pegawai toko 212 mart melakukan pendataan belanja. Metodologi yang dilakukan dalam penelitian yaitu menggunakan Model Waterfall. Model Waterfall menyediakan alur hidup perangkat lunak secara sekuensial dan terurut dimulasi dari analisis, desai, pengodean, pengujian dan tahap pendukung [5].

Tahapan-tahapan metodologi Waterfall adalah sebagai berikut.

3.1 Analisis Kebutuhan Perangkat Lunak

Proses pengumpulan kebutuhan dilakukan secara intensif untuk mespefikasikan kebutuhan perangkat lunak agas dapat dipahami perangkat lunak seperti apaya yang dibutuhkan oleh user [5]. 3.2 Desain 
Desain perangkat lunak adalah proses multi langkah yang fokus pada desain pembuatan program perangkat lunak termasuk struktur data, arsitektur perangkat lunak, representasi antarmuka, dan prosedur pengodean. Tahap ini mentranlasi kebutuhan desain agar dapat diimplementasikan menjadi program pada tahap selanjutnya[5].

3.3 Pembuatan Kode Program

Desain harus ditranslasikan kedalam program perangkat lunak. Hasil dari tahap ini adalahh program komputer sesuai dengan desain yang dibuat pada tahap desain [5].

\subsubsection{Pengujian}

Pengujian fokus pada perangkat lunak secara dari segi logik dan fungsional dan memastikan bahwa semua bagian sudah diuji. Hal ini dilakukan untuk meminimalisir kesalahan (error) dan memastikan keluaran yang dihasilkan sesuai dengan yang diinginkan [5].

\section{Hasil dan Pembahasan}

\subsection{Analisis Permasalahan}

Dalam tahap analiasis permasalahan penulis menggunakan kerangka PIECES Untuk mengetahui permasalahan yang ada. kerangka PIECES dapat dilihat sebagai berikut :

1. Performance

Waktu untuk pencarian informasi mengenai data jumlah belanja anggota agak lama

2. Information

Sulitnya untuk mengetahui jumlah belanja setiap anggota perbulan atau perhari

3. Economics manual

Mahalnya biaya pencatatan menggunakan

4. Control

Penulis tidak menemukan masalah pada kerangka PIESCES bagian pengawasan toko dan keamanan komputer

5. Efficiency

Kurangnya maksimal penggunaan computer toko dan internet yang terhubung ke komputer

6. Service

Tidak ada fasilitas untuk mengetahui belanja anggota pertahun atau perbulan

\subsection{Analisis Kebutuhan}

Digunakan untuk mengambarkan interaksi antara pengguna (user) dengan system informasi pendataan belanja anggota berbasis web. Dalam use case ini terdiri dari
Satu aktor pada aplikasi yang ada dikomputer kasir toko yaitu Pegawai kasir dan dua aktor pada website yaitu pengurus toko.

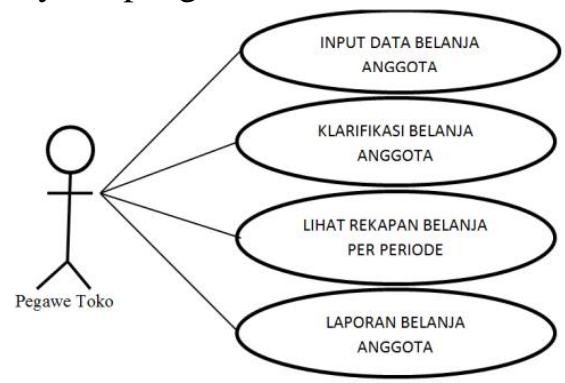

Gambar 1. Use case pegawai toko

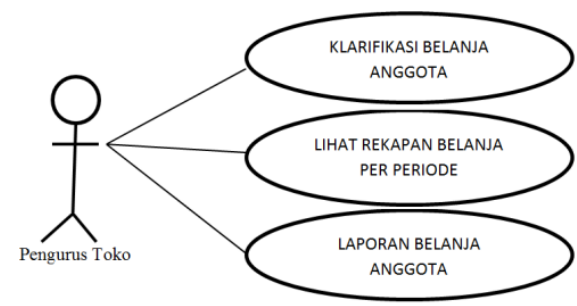

Gambar 3.4 Use case pengurus toko

\subsection{Rancangan Sistem}

\subsubsection{Diagram Konteks}

Diagram konteks merupakan diagram yang mengambarkan kondisi sebuah sistem secara keseluruhan, baik itu proses masukan dan keluaran yang dilakukan sebuah sistem. Dalam diagram konteks ini terdiri dari tiga entitas ekternal yaitu Pegawai toko, Pengurus toko dan Anggota. Pelanggan bisa melihat informasi promosi, sedangkan Pemilik Bisnis dapat mengelola promosi dan administrator bisa mengelola promosi, mengelola client dam mengelola lokasi disisi web service.

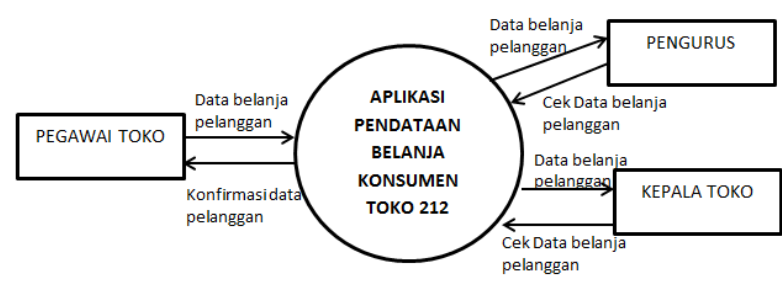

Gambar 3. Diagram konteks aplikasi

\subsection{Pengujian Aplikasi}

Aplikasi pengelolaan data belanja toko212 yaitu suatu perangkat lunak komputer yang dikembangkan untuk membantu pegawai toko melakukan pendataan belanja anggota. Dengan kata lain Aplikasi pengelolaan data belanja toko212 merupakan aplikasi komputer yang dikembangkan oleh penulis sendiri. Tujuan utama dari Aplikasi pengelolaan data belanja toko212 adalah memudahkan pegawai toko212 
melakukan pendataan belanja dan anggota bisa mengetahui total belanjanya. Secara khusus Aplikasi pengelolaan data belanja toko212 diharapkan dapat membantu pendataan belanja anggota dengan mudah. Dalam Aplikasi pengelolaan data belanja toko212, pegawai toko 212 dipasang aplikasi di komputer kasir.

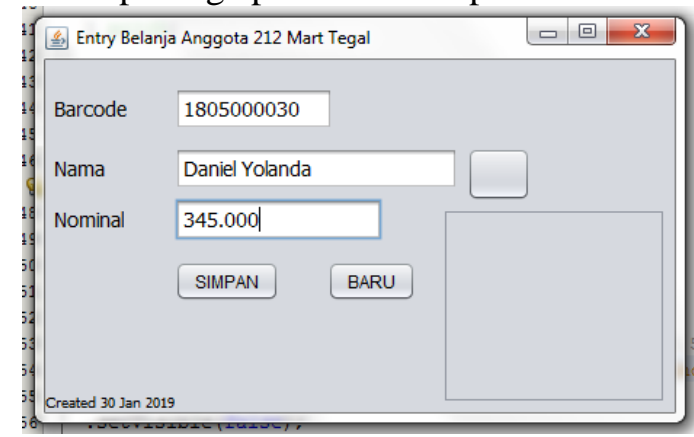

Gambar 4. Entry Data Belanja Anggota

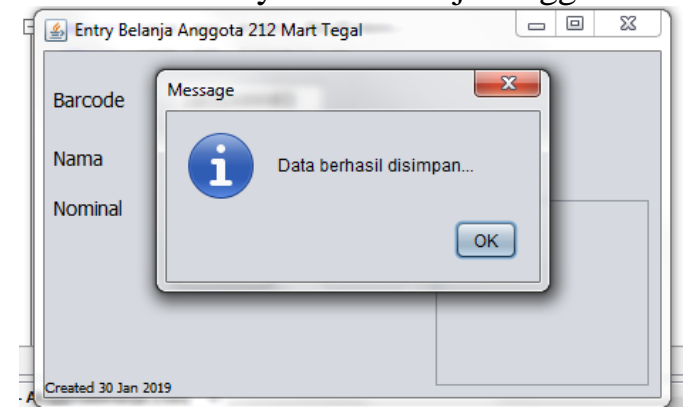

Gambar 5. Klarifikasi sudah tersimpan

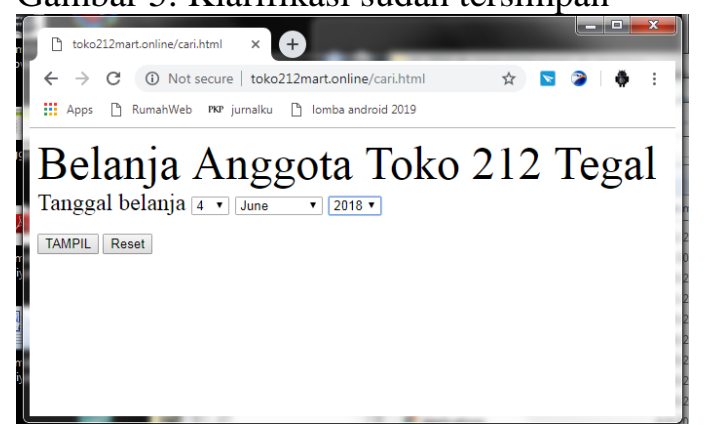

Gambar 6. Cari Data Belanja

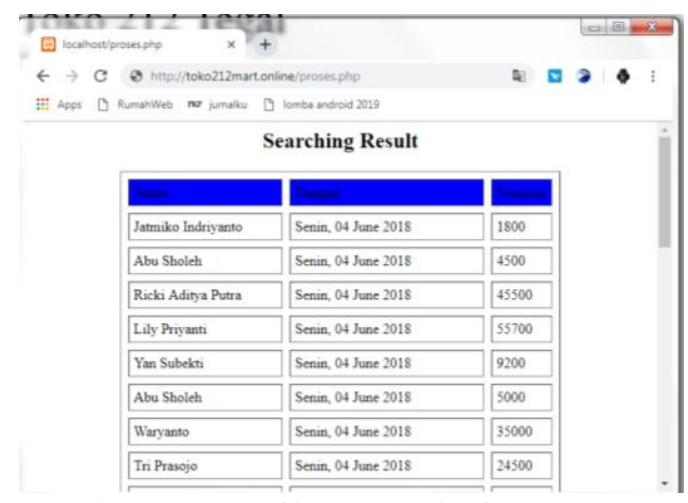

Gambar 7. Tampil Data Belanja

\section{Alur Sistem}

Urutan penggunaan aplikasi pendataan belanja Toko 212 adalah sebagai berikut:

1. Pastikan computer konek kekomputer sebelum menggunakan aplikasi, karena data dari aplikasi tersimpan di internet

2. Pegawai toko mescan kartu anggota took

3. Maka barcode dan nama akan muncul di aplikasi(Gambar 1), jika anggota tidak membawa kartu anggota, bisa menyebutkan nama saja, maka akan keluar kode barcodenya

4. Pegawe toko memasukkan nominal belanja anggota kemudian tekan tombol Enter

5. Tekan tombol simpan, sampai muncul tulisan data sudah tersimpan

6. Jika sudah tersimpan seharian penuh, kita sebagai pegawe atau pengurus toko bisa melihat rekapan harian melalui web, dengan alamat http://toko212mart.online/cari.html

7. Pada halaman tersebut bisa memasukkan tanggal belanja yang ingin ditampilkan rekapannya, jika sudah klik tombol tampil

8. Maka akan muncul rekapannya(Gambar 4)

\subsection{Pengujian Sistem}

Aplikasi promosi rempeyek kacang desa srowot berbasis android ini telah melalui uji Black Box dan WhiteBox dan diperoleh hasil:

1. Black Box Testing

Semua fungsi perangkat lunak telah berjalan semestinya sesuai dengan kebutuhan fungsional yang telah didefinsikan.

2. White Box Testing

Tidak ditemukan kesalahan logika pada sistem dan sistem dapat berfungsi dengan baik.

Berdasarkan kuesioner yang dibagi ke beberapa anggota masyrakat di Desa Srowot, hasilnya sebagai berikut:

\section{Kesimpulan}

Berdasarkan uji aplikasi beberapa kali dan kuesioner yang diisi oleh anggota masyarakat, maka diambil kesimpulan aplikasi pendataan belanja konsumen toko 212 mart tegal sudah sesuai dan bisa untuk pendataan belanja pelanggan toko.

\section{Daftar Pustaka}

[1] Benny Bunandar, "Aplikasi m-commerce berbasis android pada toko "fani bags"," TI-Atma STMIK Atma Luhur Pangkalpinang, 2015.

[2] Gina Tesaria Marjito, "Aplikasi penjualan online berbasis android (studi kasus: ditoko 
hoax merch)," Computech \& Bisnis, pp. 40-49, 2016.

[3] Windi Luki Lestari, "Aplikasi sistem informasi pembelian dan penjualan pada toko citra computer Cilacap," Pro Bisnis, vol. 3, no. 2, Agustus 2010.

[4] Fendi Nurcahyono, "Pembangunan Aplikasi Penjualan Dan Stok Barang Pada Toko Nuansa Elektronik Pacitan," Speed - Sentra Penelitian Engineering dan Edukasi, vol. 4, no. 3, 2012.

[5] Wellia Shinta Sari Hendi Wijaya, "Rancang bangun mobile commerce berbasis android pada toko duta buku Semarang,"

Techno.COM, vol. 14, no. 2, Mei 2015.

[6] Ester Lumba Alexander Waworuntu, "Pengembangan aplikasi kasir dan pengelolaan stok berbasis web studi kasus: toko xyz,"

Seminar Nasional Sains dan Teknologi , 2017.

[7] Yohanes Ulu Mado Sinta Rukiastiandari, "Rancang Bangun Aplikasi Penjualan Perlengkapan Olahraga (Studi Toko Baratha Sports)," Teknik Komputer Amik BSI, vol. V, no. 1, Februari 2019. 